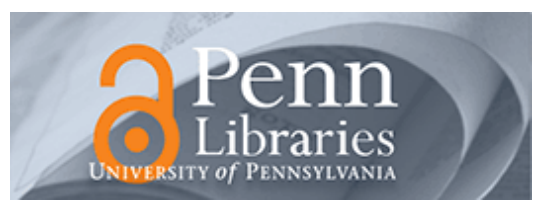

Manuscript Studies

Volume 5 | Issue 2

Article 2

2021

\title{
An Illuminated Manuscript from Late Fourteenth-Century Shiraz in the Bodleian Library
}

Cailah Jackson

Oxford Centre for Islamic Studies, cailahjackson@gmail.com

Follow this and additional works at: https://repository.upenn.edu/mss_sims

Part of the Medieval Studies Commons, and the Near Eastern Languages and Societies Commons

\section{Recommended Citation}

Jackson, Cailah (2021) "An Illuminated Manuscript from Late Fourteenth-Century Shiraz in the Bodleian Library," Manuscript Studies: Vol. 5 : Iss. 2 , Article 2.

Available at: https://repository.upenn.edu/mss_sims/vol5/iss2/2

This paper is posted at ScholarlyCommons. https://repository.upenn.edu/mss_sims/vol5/iss2/2

For more information, please contact repository@pobox.upenn.edu. 


\title{
An Illuminated Manuscript from Late Fourteenth-Century Shiraz in the Bodleian Library
}

\begin{abstract}
Islamic manuscript illumination production in the eastern Iranian city of Shiraz in the late fourteenth century marked an aesthetic sea-change from mid-fourteenth-century styles that were characterized by polychrome palettes and thick, gold strapwork. The new style of illumination, which was produced under the Muzaffarid dynasty (1314-93), was distinguished by the dominance of deep blue pigments as well as black and gold and the use of minute floral sprays and 'baroque- edged' inscribed cartouches. This profound visual shift eventually developed into the elaborate styles of Timurid, Turcoman and Safavid illumination of the fifteenth and sixteenth centuries onwards and is thus of central importance to the history of the Islamic arts of the book. This article builds upon existing scholarship by bringing to light an illuminated manuscript from late fourteenth-century Shiraz that is currently unknown to scholarship. This manuscript - an undated copy of the Kulliyat (Collection) of the Shirazi author Sa'di (d. 1291) - is richly illuminated and is thus a significant addition to the body of known material from the region. The article gives an account of the political and artistic contexts in which the manuscript was produced before providing a brief overview of known contemporary manuscript material. After an examination of the manuscript itself, the article highlights its visual links to other Muzaffarid and early Timurid material, in an effort to narrow the possible date range of production. Finally, in an effort to advance the general study of Muzaffarid manuscripts and the late medieval Islamic arts of the book, all but one of the article's reproductions have never before been published.
\end{abstract}

\section{Keywords}

Islamic art, Illuminated manuscripts, Calligraphy, Poetry, Sa'di, Shiraz, Medieval, Muzaffarid, Timurid 


\section{MAnUSCRIPT Studies}

A Journal of the Schoenberg Institute for Manuscript Studies

VOLUME 5, NUMBER 2

(Fall 2020)

Manuscript Studies (ISSN 2381-5329) is published semiannually

by the University of Pennsylvania Press

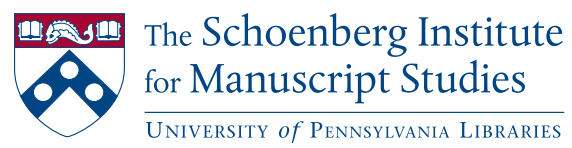




\title{
MANUSCRIPT STUDIES
}

V O L U M 5, N U M B R 2

(Fall 2020)

ISSN 2381-5329

\begin{abstract}
Copyright (c) 2020 University of Pennsylvania Libraries and University of Pennsylvania Press. All rights reserved.

Published by the University of Pennsylvania Press, 3905 Spruce Street, Philadelphia, PA 19104.
\end{abstract}

Printed in the U.S.A. on acid-free paper.

Manuscript Studies brings together scholarship from around the world and across disciplines related to the study of premodern manuscript books and documents, with a special emphasis on the role of digital technologies in advancing manuscript research. Articles for submission should be prepared according to the Chicago Manual of Style, $16^{\text {th }}$ edition, and follow the style guidelines found at http://mss.pennpress.org.

None of the contents of this journal may be reproduced without prior written consent of the University of Pennsylvania Press. Authorization to photocopy is granted by the University of Pennsylvania Press for libraries or other users registered with Copyright Clearance Center (CCC) Transaction Reporting Service, provided that all required fees are verified with CCC and paid directly to CCC, 222 Rosewood Drive, Danvers, MA 01923. This consent does not extend to other kinds of copying for general distribution, for advertising or promotional purposes, for creating new collective works, for database retrieval, or for resale.

2020 SUBSCRIPTION INFORMATION:

Single issues: $\$ 30$

Print and online subscriptions: Individuals: \$40; Institutions: \$94; Full-time Students: \$30 International subscribers, please add $\$ 19$ per year for shipping.

Online-only subscriptions: Individuals: $\$ 32$; Institutions: $\$ 82$

Please direct all subscription orders, inquiries, requests for single issues, address changes, and other business communications to Penn Press Journals, 3905 Spruce Street, Philadelphia, PA 19104. Phone: 215-573-1295. Fax: 215-746-3636. Email: journals@pobox.upenn.edu. Prepayment is required. Orders may be charged to MasterCard, Visa, and American Express credit cards. Checks and money orders should be made payable to "University of Pennsylvania Press" and sent to the address printed directly above.

One-year subscriptions are valid January 1 through December 31 . Subscriptions received after October 31 in any year become effective the following January 1. Subscribers joining midyear receive immediately copies of all issues of Manuscript Studies already in print for that year.

Postmaster: send address changes to Penn Press Journals, 3905 Spruce Street, Philadelphia, PA 19104.

Visit Manuscript Studies on the web at mss.pennpress.org. 


\title{
An Illuminated Manuscript from Late Fourteenth-Century Shiraz in the Bodleian Library
}

\author{
CAILAH JACKSON \\ Oxford Centre for Islamic Studies
}

His ARTICLE Discusses a hitherto-overlooked Persian manuscript
in the Bodleian Library (MS Elliott 220, ${ }^{1}$ see Appendix, no. 1, at
the end of the article): an undated copy of the Kulliyat (Collection)
of the poet Abu 'Abdallah Musharrif al-Din ibn Muslih Sa'di-i Shirazi,
otherwise known by the pen name Shaykh Sa'di. The manuscript is

The work for this article was conducted during my tenure as a Bahari Visiting Fellow in the Persian Arts of the Book at the Bodleian Library, Oxford. I would like to thank the library wholeheartedly for its generous financial and practical support and for allowing me to examine and publish some of the manuscripts discussed in this paper. Thank you also to the British Library, Sotheby's, the Topkap1 Palace Museum, and the Museum of Turkish and Islamic Arts for their permission to publish images from their collections. A previous version of this article was presented as a conference paper at Symposia Iranica (St Andrews, United Kingdom, 13-14 April 2019), and I am grateful to the audience for their useful feedback. Finally, I am sincerely thankful to the anonymous reviewers of the article for their valuable and thought-provoking comments and suggestions.

1 Eduard Sachau and Hermann Ethé, eds., Catalogue of the Persian, Turkish, Hindûstânî, and Pusht $\hat{u}$ Manuscripts in the Bodleian Library: Part I, The Persian Manuscripts (Oxford: Clarendon, 1888), 533-54 (no. 686). 
illuminated but not illustrated. ${ }^{2} \mathrm{Sa}^{\mathrm{c}} \mathrm{di}$, one of the most renowned writers of medieval Iran, was born in Shiraz sometime between 1213 and 1219 and died there on 27 Dhu-l-Hijja 691 (9 December 1292). He is the author of several works of classical Persian poetry and prose, including the epic poem Bustan (The Orchard) completed in 1257, the prosimetrum Gulistan (The Rose Garden) written in 1258 (both compilations of moralizing tales), as well as several panegyrics (qasidas), lyric poems (ghazals), and shorter epigrammatic poems (qit'as and rubais). ${ }^{3}$ The Bodleian copy includes all of these texts and indeed appears to be a complete collection of Sa'di's works (apart from six prose treatises attributed to the author). ${ }^{4} \mathrm{Sa}$ 'di's writings, collected or otherwise, were extremely popular throughout the Islamic world from the medieval period onward, and numerous manuscripts of his oeuvre survive. As a manuscript, his Kulliyat was produced from at least the early fourteenth century and possibly earlier. ${ }^{5}$

2 "Illustration" being figural painting and "illumination" being nonfigural painted decoration using gold.

3 Richard Davis, "Sa cīi," Encyclopaedia of Islam, 2nd ed., ed. Peri Bearman, Thierry Bianquis, Clifford Edmund Bosworth, Emeri van Donzel, and Wolfhart P. Heinrichs, accessed 23 May 2019, http://dx.doi.org/10.1163/1573-3912_islam_SIM_6416.

4 See Sachau and Ethé, Catalogue. Further work needs to be done to establish the authorship of some of the six attributed treatises (risälat). For others, such as the Pandnama (Book of Advice), the attribution is considered by scholars to be erroneous. See Davis, "Sa 'dî."

5 The earliest known copy dates from after 1284 (since it mentions the Ilkhanid statesman Shams al-Din Juvayni as already being dead) and was possibly written in the final decade of the thirteenth century. The thirteenth-century portion is incomplete, with other parts dating to the fourteenth, sixteenth and eighteenth centuries (Dublin, Chester Beatty Library, Per 109). See Arthur John Arberry, Mojtaba Minovi, and Edgar Blochet, The Chester Beatty Library: A Catalogue of the Persian Manuscripts and Miniatures, ed. J. V. S. Wilkinson, 3 vols. (Dublin: Hodges, Figgis \& Co, 1959), 1:22-23 (no. 109); and Elaine Wright, The Look of the Book: Manuscript Production in Shiraz, 1303-1452 (Washington, DC: Freer Gallery of Art and Arthur M. Sackler Gallery; Seattle: University of Washington Press; Dublin: Chester Beatty Library, 2012), figs. 8-9. As far as I know, the earliest (partial) copy with a secure date was recently sold at Christie's (Lot 30, Sale 1557, Art of the Islamic and Indian Worlds, 9 October 2014). The manuscript is dated to 6 Ramadan 718 (1 November 1318), and its illumination suggests that it was almost certainly produced in Iran. 


\section{Political, Artistic, and Scholarly Contexts}

The Bodleian Kulliyat was undoubtedly produced in the late fourteenth century in Shiraz. In 1335, Abu Said (r. 1316-35), the last ruler of the Mongol Ilkhanid empire, which had ruled over all of present-day Iran, most of Iraq and Central Asia, and parts of eastern Anatolia from the midthirteenth century, died without an heir and instigated a succession crisis from which the empire did not recover. In the wake of the Ilkhanate's collapse, several rival successor states emerged in the region, including the Muzaffarids (1314-93), Jalayirids (1335-1432), Injuids (1325-53), and Chupanids (1335-57). Apparently of Arab and Khurasani heritage, the Muzaffarids originally migrated to Iran as a result of the Mongol advance in the thirteenth century. ${ }^{6}$ The family's status greatly improved in 1318, when, at the age of seventeen, Mubariz al-Din Muhammad (d. 1363-64) was appointed governor of Yazd by Abu Sa id. ${ }^{7}$ Following the disintegration of the Ilkhanate, Mubariz al-Din acquired Kerman in 1340, Shiraz in 1353, and Isfahan in 1356. ${ }^{8}$ A few years later in 1358/9, the Muzaffarid ruler was blinded and imprisoned by his sons and nephew, who were apparently resentful about the ruler's favoritism toward his grandson, Shah Yahya. ${ }^{9}$ After the overthrow of Mubariz al-Din, Muzaffarid lands were divided between his sons and grandsons. Conflict soon arose between many of these rulers, particularly Shah Shuja and Shah Mahmud, who spent most of the 1360s to 1380 s fighting over territory. The dynasty was finally ended by the warlord Timur (r. 1370-1405), who executed the seventy surviving members of the house on 11 Rajab 795 (23 May 1393). ${ }^{10}$

6 Peter Jackson, "Muzaffarids," in Encyclopaedia of Islam, 2nd ed., ed. Peri Bearman, Thierry Bianquis, Clifford Edmund Bosworth, Emeri van Donzel, and Wolfhart P. Heinrichs, accessed 24 May 2019, http://dx.doi.org/10.1163/1573-3912_islam_SIM_5688.

7 Patrick Wing, "Mozaffarids," Encyclopaedia Iranica, online edition, accessed 24 May 2019, http://www.iranicaonline.org/articles/mozaffarids.

8 Wing, "Mozaffarids."

9 Jackson, "Muzaffarids," and Wing, "Mozaffarids," date this event to 1358 and 1359, respectively.

10 Wing, "Mozaffarids"; Robert Hillenbrand, "Muzaffarid Family," Grove Art Online, accessed 24 May 2019, https://doi.org/10.1093/gao/9781884446054.article.T060625. 
Despite the near-constant internecine violence, many significant works of architecture, art (particularly manuscripts and metalwork), and poetry were produced under Muzaffarid rule. ${ }^{11}$ For instance, their reign saw the ascendancy of the celebrated poet Hafiz (d. 1389-90), whose collected works are still considered to be one of the preeminent cultural achievements of classical Persian literature.

In the realm of the arts of the book, around thirty illuminated and/or illustrated manuscripts survive that are ascribed by scholars to late fourteenth-century Shiraz (or nearby cities) on the basis of their inscriptions, illuminations, or illustrations. Only one of this group of manuscripts (Appendix, no. 2) is explicitly linked to the patronage of a Muzaffarid ruler (Shah Yahya), while another was compiled, translated, and copied by Shah Shuja's personal physician (Appendix, no. 3). ${ }^{12}$ Other named patrons of illustrated or illuminated manuscripts tended to be viziers, whose positions were generally more long-term and stable in comparison to princes (see, for example, Appendix, nos. 4-5). ${ }^{13}$ By and large, the types of text that were decorated in the Muzaffarid era (with illumination, figural illustration, or both) were works of poetry, such as Divan-i Kabir (Appendix, no. 6 and fig. 1), the Khamsa of Nizami (Appendix, nos. 7-8 and fig. 2), and the Shabnama (Appendix, no. 9 and fig. 3). Nonpoetic works include Qur'ans

11 On metalwork and architectural decoration, respectively, see, for instance, Sheila Blair, "Artists and Patronage in Late Fourteenth-Century Iran in the Light of Two Catalogues of Islamic Metalwork," Bulletin of the School of Oriental and African Studies 48, no. 1 (1985): 53-59; and Bernard O'Kane, "The Bihbihani Anthology and Its Antecedents," Oriental Art 45, no. 4 (1999-2000): 9-18. On Muzaffarid manuscripts in general, see Wright, The Look of the Book.

12 The dedication to Shah Yahya appears on fol. 1a of Appendix, no. 2. See Francis Richard, Splendeurs Persanes: manuscrits du XIIe au XVIIe siècle (Paris: Bibliothèque nationale de France, 1997). On Appendix, no. 3, see Wright, The Look of the Book, 61 (Table 12C), 251, 367 n. 31 , and 370 n. 5.

13 Wright, The Look of the Book, 62. For some examples of Muzaffarid-era manuscripts dedicated to viziers, see Oleg Akimushkin and Basil Gray, eds., The Arts of the Book in Central Asia, 14th-16th Centuries (London: Serindia; Paris: UNESCO, 1979), 7, fig. 20; Wright, The Look of the Book, fig. 119C and app. 4.5; and David James, The Master Scribes: Qur'ans of the 10th to 14 th Centuries $A D$ (London: The Nour Foundation in association with Azimuth Editions and Oxford University Press, 1992), nos. 29-30. 


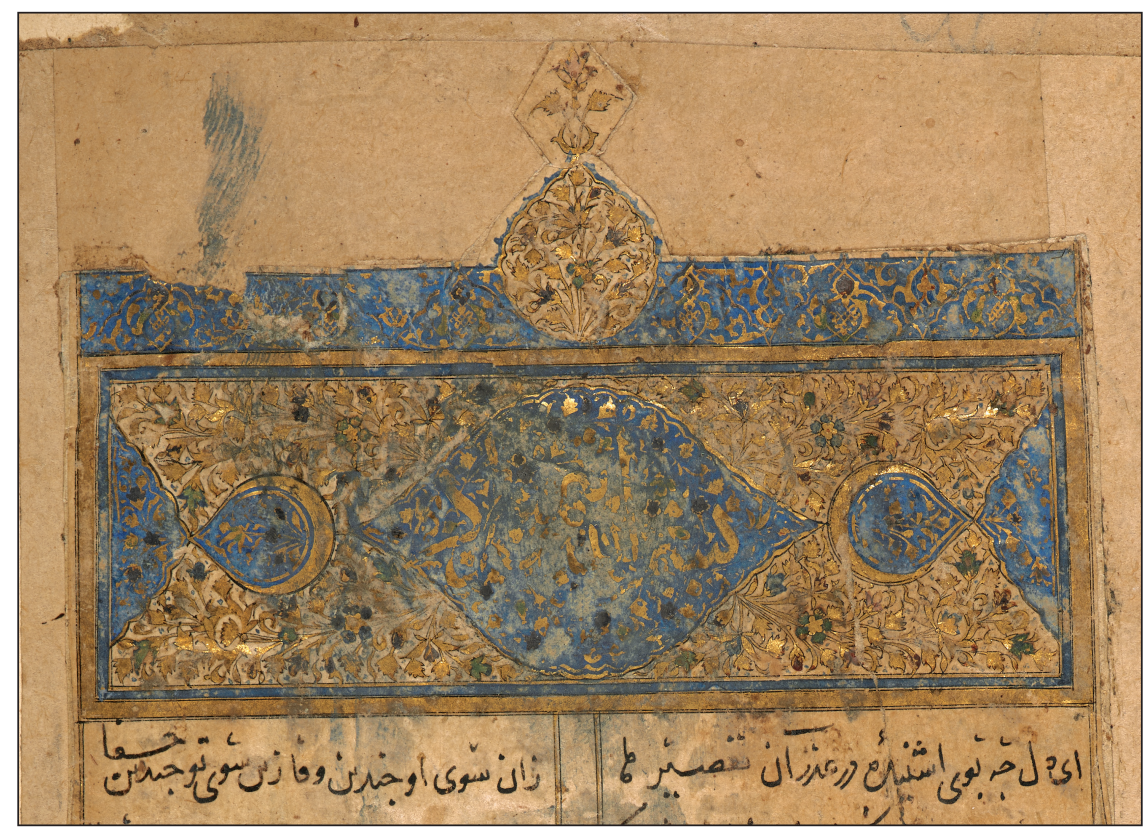

FIGURE 1. Headpiece, Divan-i Kabir, 1372, Shiraz (probably). London, British Library, Or. 2866, fol. 2b. ㄷ British Library Board.

(Appendix, no. 4 and fig. 4), historical chronicles (Appendix, no. 10), and one medical text (Appendix, no. 3). The Kulliyat presently under discussion combines both prose and poetry. It is, thus far, the only copy of this text that we can associate with late fourteenth-century Shiraz. Considering the contemporary fame of the poet Hafiz, it is perhaps notable that no copies of his work produced in Shiraz in the late fourteenth century have survived. ${ }^{14}$

The surviving corpus of illuminated manuscripts from Muzaffarid-era Shiraz allows us to readily identify the key aspects of nonfigural decoration from this period, not least due to its visual distinctiveness. Some of these features include the extensive use of deep blue, as well as black and gold;

14 The earliest dated manuscript that contains ghazals by Hafiz was completed in 1400-1401 but was probably begun several years earlier in India. See Julie Scott Meisami, "Hafez v. Manuscripts of Hafez," Encyclopaedia Iranica, online edition, accessed 24 May 2019, http:// www.iranicaonline.org/articles/hafez-v. 
Manuscript Studies, Vol. 5 [2021], Iss. 2, Art. 2

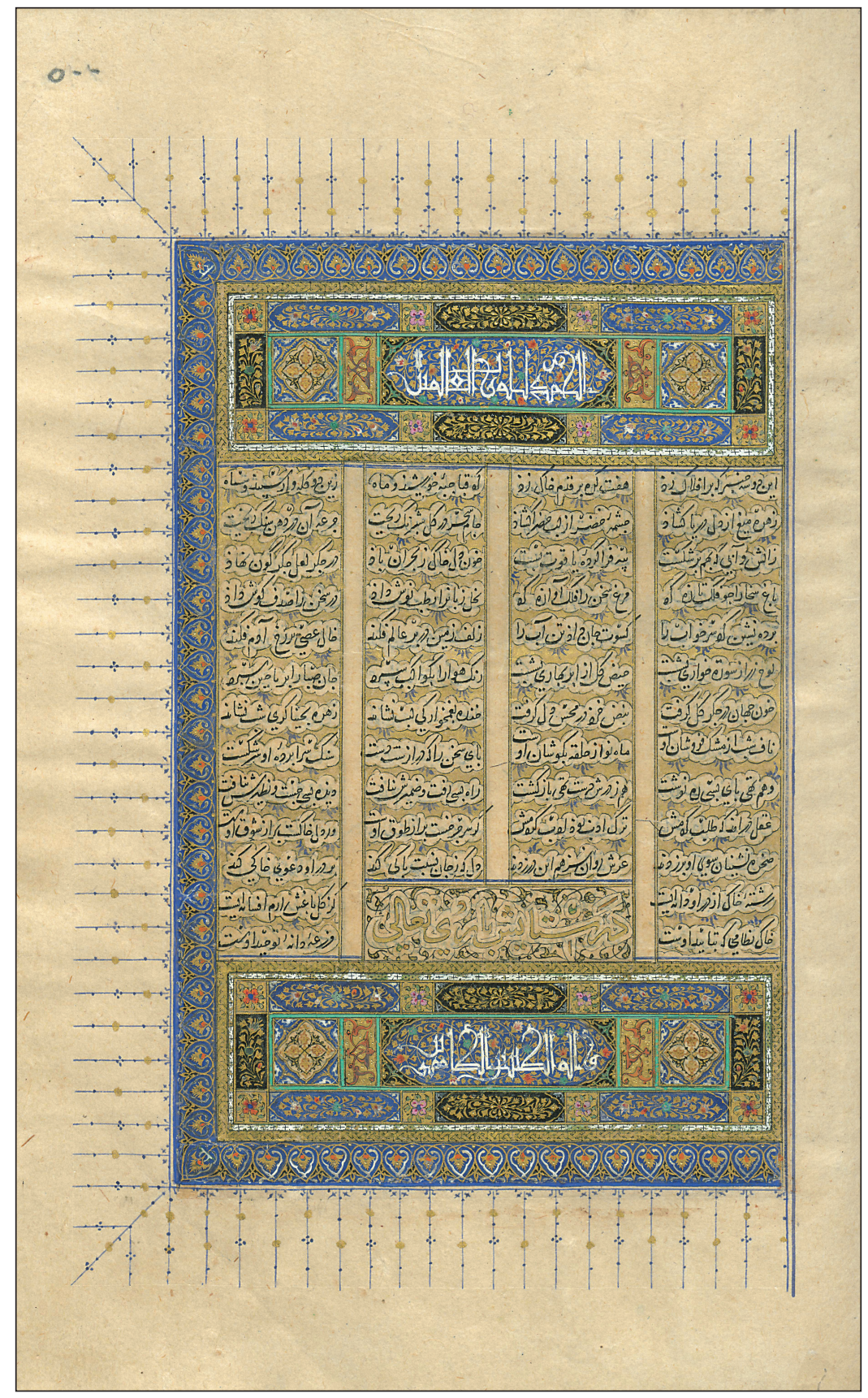

$\oplus$

FIGURE 2. Illuminated text page, Khamsa, 1374-5, Shiraz. Istanbul, Topkapı Palace Museum, H. 1510, fol. 500a. (C) Topkapı Palace Museum. 
260 | Journal for Manuscript Studies

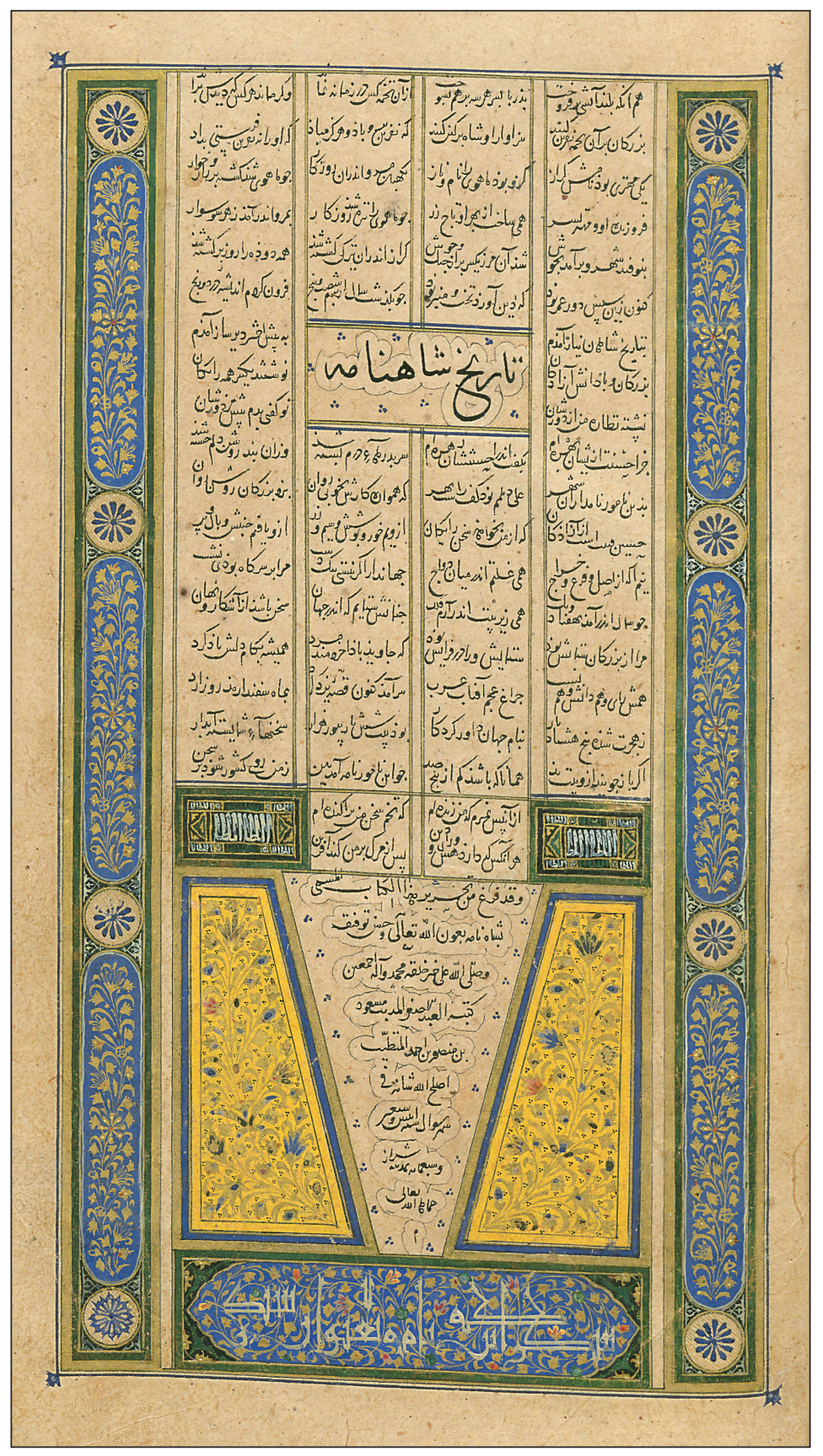

FIGU RE 3. Colophon, Shahnama, 1371, Shiraz. Istanbul, Topkapı Palace Museum, H. 1511, fol. 288a. (C) Topkapı Palace Museum. 


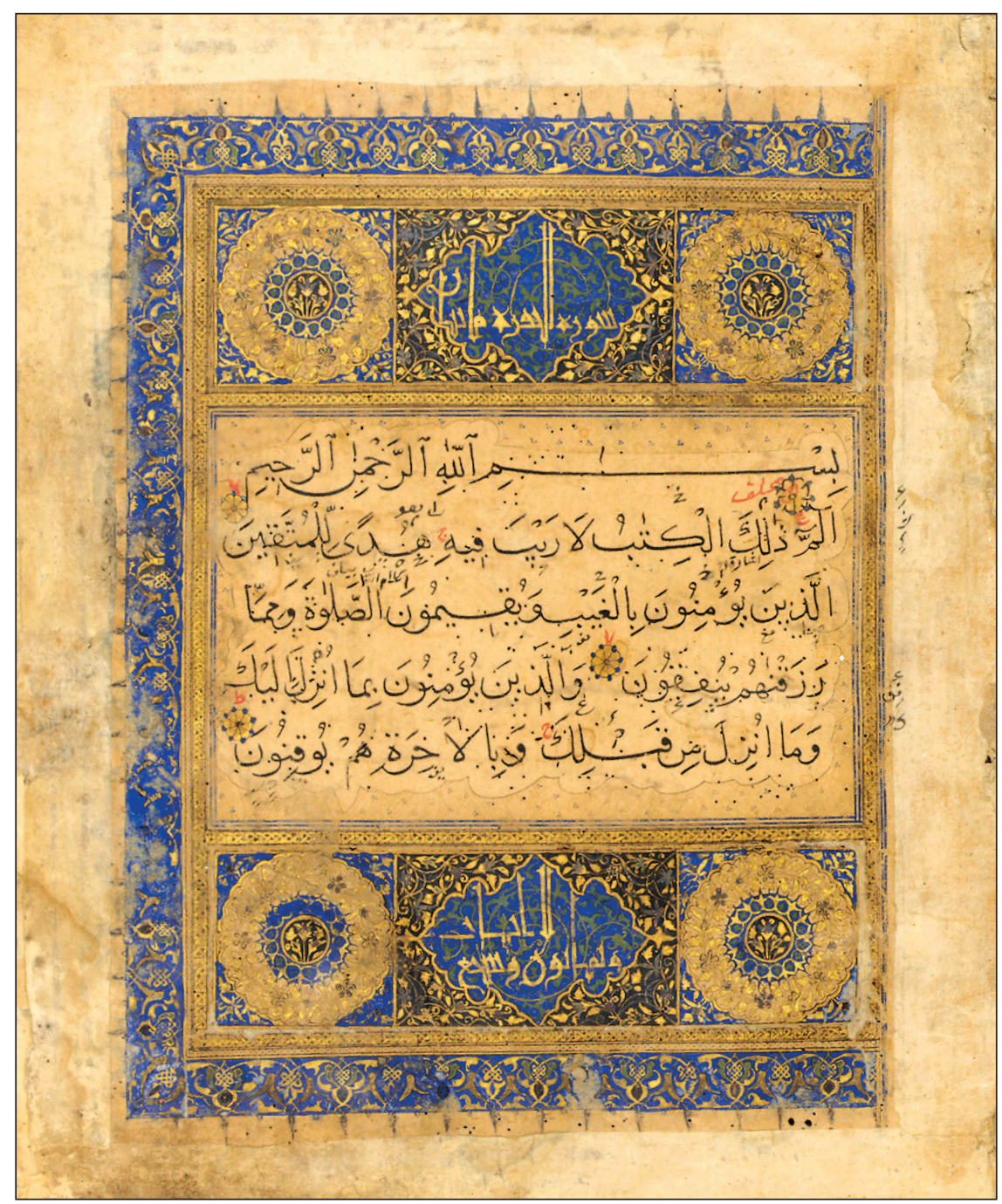

FIGURE 4. Illuminated text page, Qur'an, Shiraz (probably). Private Collection, fol. 2a. (C) Photo courtesy of Sotheby's, 2019.

minute, gold floral sprays; "baroque-edged" inscribed cartouches; cloud collar or cloud collar-like shapes; relatively slim gold frames (either plain or consisting of strapwork); intricate split palmette (or "palmette-arabesque") borders; and "pricking" of some gold areas with a sharp implement in order to catch the light (see fig. 4 for an example of some of these visual features). 
For the most part, these motifs were not seen in the illumination of previous decades, although we do see early versions of some of these elements in the illumination of the Injuid dynasty (1335-57) of Shiraz. ${ }^{15}$ For instance, a Qur'an produced for the Injuid princess Fars Malik Khatun sometime in the 1340s or 1350s (Appendix, no. 4) contains thin gold strapwork and delicate floral sprays on a slightly larger scale than the floral sprays commonly seen in Muzaffarid illumination. ${ }^{16}$ The Stephens Shabnama from roughly the same period, probably produced in Shiraz, is illuminated in a palette that moves toward mostly blue and gold (along with red and green). This transitional style of decoration eschews the polychrome appearance of Ilkhanid illumination of the early fourteenth century and heralds the advent of the blue-dominated aesthetic of later fourteenth-century Shirazi manuscripts. ${ }^{17}$

Although the reign of the Muzaffarids was relatively short and fraught with conflict, the style of illumination coming out of Shiraz was a profound turning point in the ornamentation of the Islamic arts of the book. The predominantly blue aesthetic was carried forward in Iran for several centuries afterwards, as were many motifs that were popularized in late fourteenth-century Shiraz, such as the cloud collar and floral sprays. The movement toward increasingly intricate motifs was part of a wider trend of complexity and "miniaturization" of detail in the Persian arts of the book that we also see in figural illustration. ${ }^{18}$ This trend for miniaturization was also reflected in the manuscripts' sizes. Unlike in earlier parts of the century, when monumental, decorated tomes were not uncommon, surviving Muzaffarid-era manuscripts are generally medium-sized, often measuring 200-300 $\mathrm{mm}$ in length and 150-200 $\mathrm{mm}$ in width.

15 Wright, The Look of the Book, 25-55.

16 On this manuscript, see James, The Master Scribes, nos. 29-30, and the citation in the previous note.

17 On this manuscript, see Wright, The Look of the Book, 28-29 (figs. 20-21), 53.

18 I thank Robert Hillenbrand for pointing this out. See David J. Roxburgh, "Micrographia: Toward a Visual Logic of Persianate Painting," Res: Anthropology and Aesthetics 43 (2003): 12-30. This trend was also evident in metalwork, as highlighted by Linda Komaroff, "Pen-Case and Candlestick: Two Sources for the Development of Persian Inlaid Metalwork," Metropolitan Museum Journal 23 (1988): 89-102. 
Despite their clear importance for the development of Persian illumination, Muzaffarid styles have not been studied in much depth, save for the thorough work done by Elaine Wright. The seeming relative lack of Muzaffarid rulers commissioning manuscripts and the concurrent role played by viziers as manuscript patrons-both mentioned above-raise the issue of the contribution of the sub-dynastic level to manuscript production and the impact this situation may have had on the modern scholarship of the Muzaffarid arts of the book. Many late thirteenth- and fourteenth-century illuminated manuscripts in neighboring Anatolia were, for example, produced not for regional rulers but rather for lesser-known bureaucrats, courtiers, and Sufi dervishes. ${ }^{19}$ At the time, Anatolia was also beset by significant and sustained political turbulence. The lack of dynastic patronage in the arts of the book of late medieval Anatolia has resulted in their comparative neglect in broader surveys of the field of Islamic manuscripts, due in part to the dynastic orientation of wider Islamic art historical narratives. ${ }^{20}$ The field's focus on dynastic production may partially account for the relative lack of attention paid to Muzaffarid manuscripts, especially in comparison to the Timurids. Several Timurid rulers and princes were prolific supporters of the arts of the book, and their activities have received much attention from scholars. ${ }^{21}$

The lower level of engagement with the development of illumination under the Muzaffarids means that many questions remain unanswered. Some of those questions, particularly those regarding the identity of scribes and patrons, may be possible to answer in the future with the discovery of

19 Cailah Jackson, Islamic Manuscripts of Late Medieval Rum, 1270s-1370s: Production, Patronage and the Arts of the Book (Edinburgh: Edinburgh University Press, 2020).

20 On this discourse, see, most recently, Finbarr Barry Flood and Gülru Necipoğlu, "Frameworks of Islamic Art and Architectural History: Concepts, Approaches, and Historiographies," in A Companion to Islamic Art and Architecture, 2 vols., ed. Finbarr Barry Flood and Gülru Necipoğlu (Hoboken, NJ: Wiley Blackwell, 2017), 1:2-56.

21 The literature is extensive, but see, for example, Thomas W. Lentz and Glenn D. Lowry, Timur and the Princely Vision: Persian Art and Culture in the Fifteenth Century (Los Angeles: Los Angeles County Museum of Art; Washington, DC: Arthur M. Sackler Gallery, 1989); and David J. Roxburgh, The Persian Album, 1400-1600: From Dispersal to Collection (New Haven, CT: Yale University Press, 2005). 
further source material. Other important matters include why the Muzaffarid style emerged so distinctly in late fourteenth-century Shiraz and why it remained popular for so long. It is, unfortunately, beyond the scope of this modest article to consider these weighty issues. The first point concerning the emergence of the Muzaffarid style is difficult to answer since we often have evidence of change but not necessarily the reasons for it. On the second point concerning longevity, David Roxburgh has discussed how the Timurid prince Baysunghur (d. 1433) was instrumental in codifying late fourteenth-century painting styles, thereby affecting figural art through to the sixteenth century. ${ }^{22}$ It could be that, as the new rulers of Shiraz (and Herat), the Timurids adopted the local Shirazi style of illumination and refined it in the context of their predilection for controlled compositions and precise execution, thus encouraging its continued popularity through the centuries.

In any case, this continued use of certain pigments and motifs makes it difficult to draw a clear line between Muzaffarid and early Timurid illumination. We can say, in a general sense, that while early Timurid illumination bears numerous similarities to Muzaffarid illumination, it is possible to see a slight shift in some respects. For example, there is a greater use of the white or cream ground of the page and the increased use of greens and reds, so that the overall appearance is still mostly dominated by blue but perhaps not to the same extent as we commonly see in Muzaffarid decoration (see fig. 5 for a very early Timurid manuscript). As mentioned below, the composition of panels of illumination becomes even more complex in the late 1390s and early fifteenth century, with increasingly divided frames and the incorporation of numerous small motifs into relatively compact spaces. There is also the use of motifs that were not common in Muzaffarid illumination, like the cruciform shape formed from four joined cloud collars. ${ }^{23}$ Again, these are very general points. Indeed, we do see the movement toward these elements in some illumination from the late Muzaffarid period, so the notion of dynastic characteristics should be used with caution and challenged

22 Roxburgh, "Micrographia," 13, 28.

23 See, for example, Wright, The Look of the Book, 74, 75, fig. 45. 


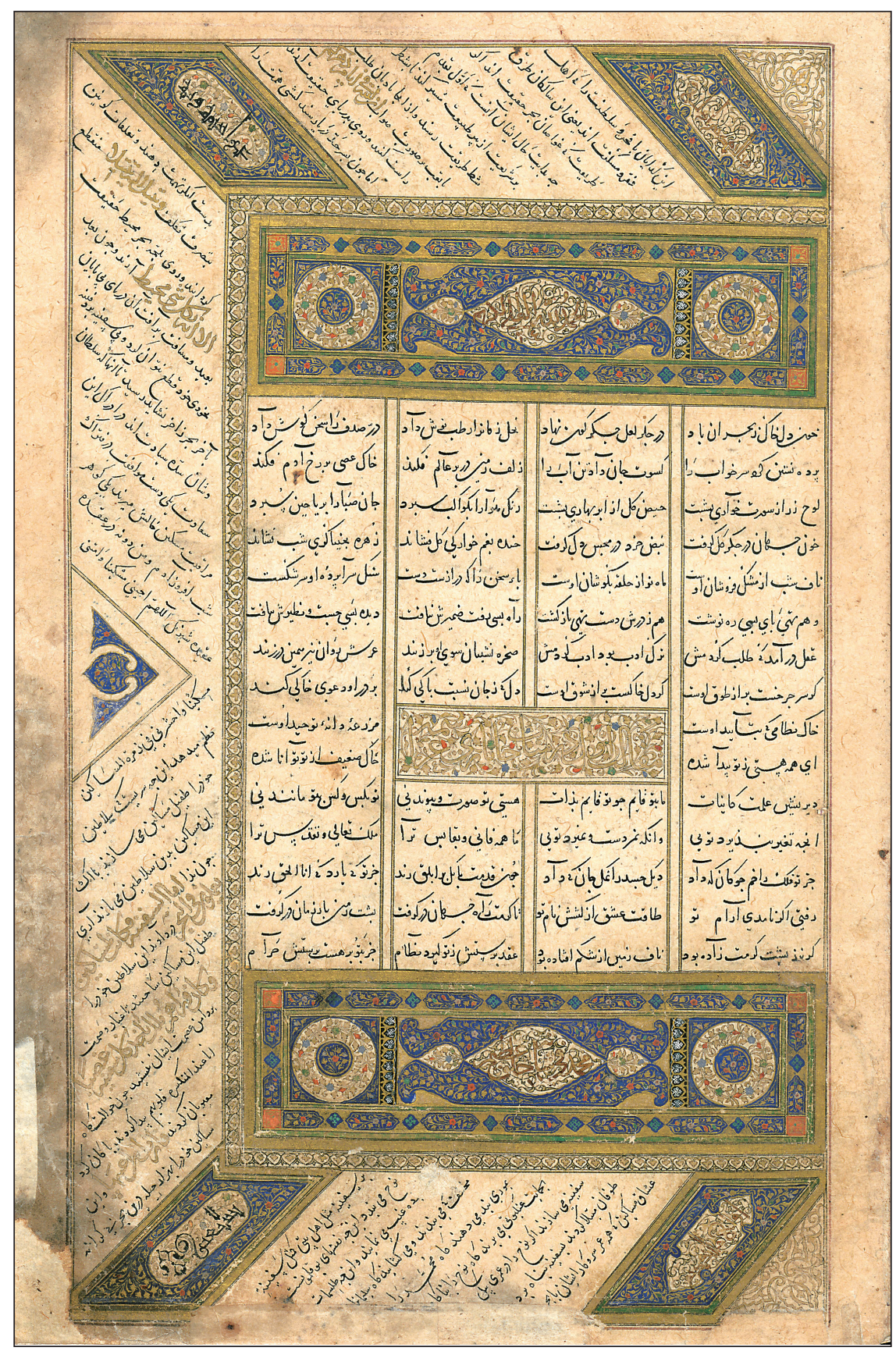

$\oplus$

FIGURE 5. Illuminated text page, Anthology, 1398, Shiraz (probably). Istanbul, Museum of Turkish and Islamic Arts, 1950, fol. 3a. C Türk ve İslam Eserleri Müze Müdürlüğ̈̈. 
in accordance with what the material evidence reveals. These visual overlaps between Muzaffarid and early Timurid manuscripts are, of course, not surprising considering that there was often some continuity in the organization and productivity of local or royal workshops with the advent of a new regime.

\section{The Bodleian Kulliyat}

The Bodleian manuscript of the Kulliyat of Sa'di consists of 444 folios and is medium-sized, measuring roughly $207 \mathrm{~mm}$ (length) by $131 \mathrm{~mm}$ (width), though it was cropped during the rebinding process. It is covered in a floral lacquer binding, common in nineteenth-century Iran, that is accompanied by a green Western-style leather spine. The manuscript's paper is a dark cream color and does not appear to have been highly burnished or polished. Horizontal laid lines are visible, with twenty lines measuring to approximately $25 \mathrm{~mm}$. There are no inscriptions or seals in the manuscript that would give us any clues related to its production or patronage. There is one later seal on folios 1b-2a, dated to $\mathrm{AH} 1199$ (1784-85 CE) and belonging to Bahadur 'Azim 'Alikhan. ${ }^{24}$

The manuscript is copied in black naskb. The script itself is very neat and evenly spaced with reasonably consistent letterforms. According to Elaine Wright's criteria for distinguishing between naskb and nasta liq script in late fourteenth-century Shiraz, the script of the Bodleian Kulliyat is very " $n a s k b$ like," with no clear tendency toward nastaliq. ${ }^{25}$ Through the analysis of selected manuscripts, Wright suggests that nastaliq started to emerge from around the mid-1350s in Shiraz. ${ }^{26}$ It was used with increasing frequency over subsequent decades, becoming the predominant script for copying poetry

24 I am unsure as to who exactly this individual was, but his name suggests that he was perhaps from South Asia.

25 Wright, The Look of the Book, 234-40. The only letterform that shows any tendency to nastaliq (and this is comparatively minimal in the author's opinion) is the kaf, which often displays a rather elongated cap.

26 Wright, The Look of the Book, 242-52. 
and many prose texts. ${ }^{27}$ There were, however, still a small number of poetry manuscripts copied in naskb even well into the fifteenth century, so the presence of naskb in this manuscript should not necessarily imply an earlier date. ${ }^{28}$ Although the main ink color is black, certain phrases and headings in the text are copied, with relative frequency, in gold, bright blue, bright red, and dark red. This unusual combination of pigments gives the manuscript's text block a comparatively colorful appearance in places. I have come across only one other example of a manuscript from the later fourteenth century that is copied in this specific group of colors (Appendix, no. 11). This is a manuscript that was completed in September 1365 and lists its author as Said al-Din Muhammad al-Kazaruni and title as Tarjuma- $i$ Mawlud-i Mustafa. ${ }^{29}$ The text is a Persian translation of the original Arabic text. ${ }^{30}$ Given the manuscript's style of illumination, it was undoubtedly produced in Shiraz. The correspondence in ink colors between the two manuscripts begs the question of whether they might have been copied by the same scribe, especially since both are copied in naskb. A closer inspection of their scripts confirms that this is not the case since, in several instances, the letterforms are decidedly different. The nun dots are one example of this. In the Kulliyat, they are placed centrally and deeply within the letter, while in the 1365 manuscript, the dots sit quite high above the main letterform and sometimes tend toward the right.

27 Wright, The Look of the Book, 254.

28 See, for example, a copy of Jalal al-Din Rumi's Masnavi-i Ma'navi probably produced in Timurid Shiraz, sold at Sotheby's on 24 April 2013 (Lot 36, Sale L13220, Arts of the Islamic World).

29 Oxford, Bodleian Library, MS Pers. d. 31. See Wright, The Look of the Book, 61, $340 \mathrm{n}$. 112. The author is almost certainly Sadid/Sa'd al-Din Muhammad ibn Mas'ud al-Kazaruni, who died in 1357 and wrote several medical texts. The Persian translation was completed by his son 'Afif al-Din in 760/1358-59. See A. F. L. Beeston, ed., Catalogue of the Persian, Turkish, Hindûstânî, and Pushtû Manuscripts in the Bodleian Library: Part III, Additional Persian Manuscripts (Oxford: Clarendon, 1954), 3 (no. 2446).

30 The work has been published in Arabic as Muhammad ibn Mas'ud al-Kazaruni, alMuntaqā min Siyar al-Nabī al-Muștafā, ed. Lutfi Mansur (Kafr Qara: Markaz Dirasat al-Adab al-'Arabi wa-Dar al-Huda li-1-Tiba'a wa-1-Nashr, 2001), and in Persian as Muhammad ibn Mas'ud al-Kazaruni, Nihāyat al-Mas'ūl fì Ravāyat al-Rasūl, ed. Muhammad Ja'far Yahaqqi, trans. 'Ali ibn Husayn Abarquhi (Tehran: Shirkat-i Intisharat-i 'Ilmi va Farhangi, 1987). 
The text block of the Kulliyat is arranged into either one column or two columns of twenty-five lines. Works of poetry are copied in two columns, while prose texts are copied in one column. It seems that, for the most part, works of poetry were copied in the four-column format by the late fourteenth century (especially after the 1360s), but the two-column format was employed occasionally throughout the fourteenth and fifteenth centuries. ${ }^{31}$ The text is decorated with a double frontispiece and double illuminated text pages that are somewhat damaged (figs. 6-7). These decorated pages have been remounted on later paper, so the original margins have been lost. The colors used to decorate the manuscript are similar to those used in other late fourteenth-century manuscripts from Shiraz in that blue is dominant, with smaller areas of gold and black. There are also small touches of green, orange, and blue that are used to denote flowers. As shown in figure 6, the full-page illuminations consist of a small, polylobed medallion (shamsa) surrounded by inscribed circles containing the manuscript's contents, framed by a square that is then set into a larger rectangle. The upper and lower panels of the design contain scallop-edged cartouches inscribed with the names of the work and author. The illuminated text pages are arranged in a similar way, with a square text panel replacing the polylobed medallion and inscribed circles.

The manuscript contains numerous headpieces that denote the beginning of each of the author's many works. However, all but one of these were probably added to the manuscript at a later date (folio 8b, fig. 8). Their style is different from that of the main illumination of the manuscript, as it uses greater areas of cream (i.e., bare paper) ground and rather elaborate cartouche shapes, some of which are more commonly seen in Timurid manuscripts from the early fifteenth century. ${ }^{32}$ The headpiece on folio $8 b$, by contrast, is decorated in bright blue and black and shows similar abrasion to

31 Wright, The Look of the Book, 125-28, 355 n. 55.

32 For example, the shapes of several of the headpiece cartouches do not, as far as can be ascertained, appear in Muzaffarid-era manuscripts. The earliest manuscript in which I have been able to find them dates from 801/1398 (Istanbul, Museum of Turkish and Islamic Arts, 1950). This manuscript is discussed in O'Kane, “The Bihbihani Anthology," but the aforementioned illuminations are unpublished. See figs. 5 and 12 in this article. 
Manuscript Studies, Vol. 5 [2021], Iss. 2, Art. 2

Jackson, Fourteenth-Century Shiraz

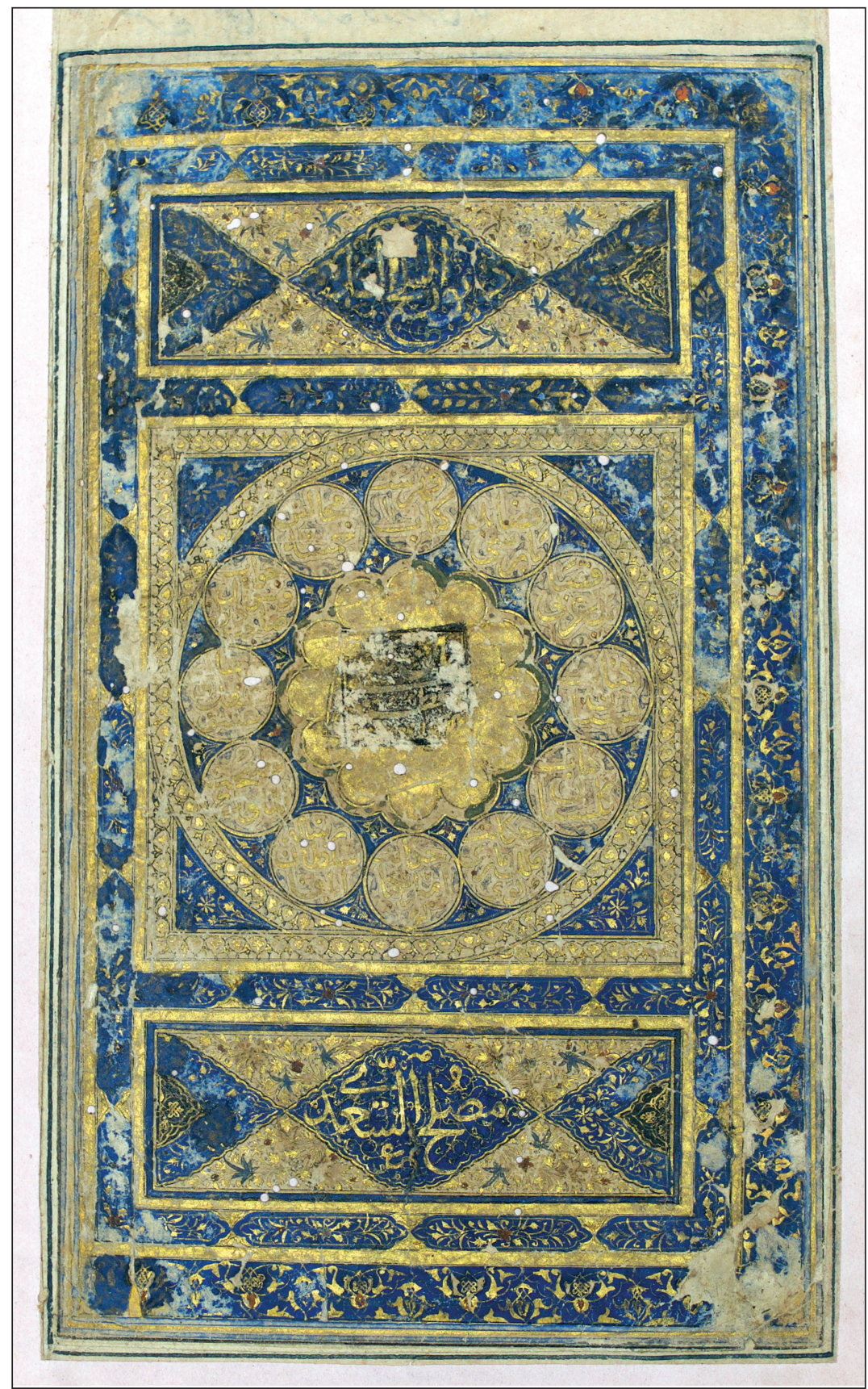

$\oplus$

FIGU RE 6. Frontispiece, Kulliyat, 1370s-90s, Shiraz (probably). Oxford, Bodleian Library, MS Elliott 220, fol. 1b. (C) The Bodleian Library, University of Oxford. 


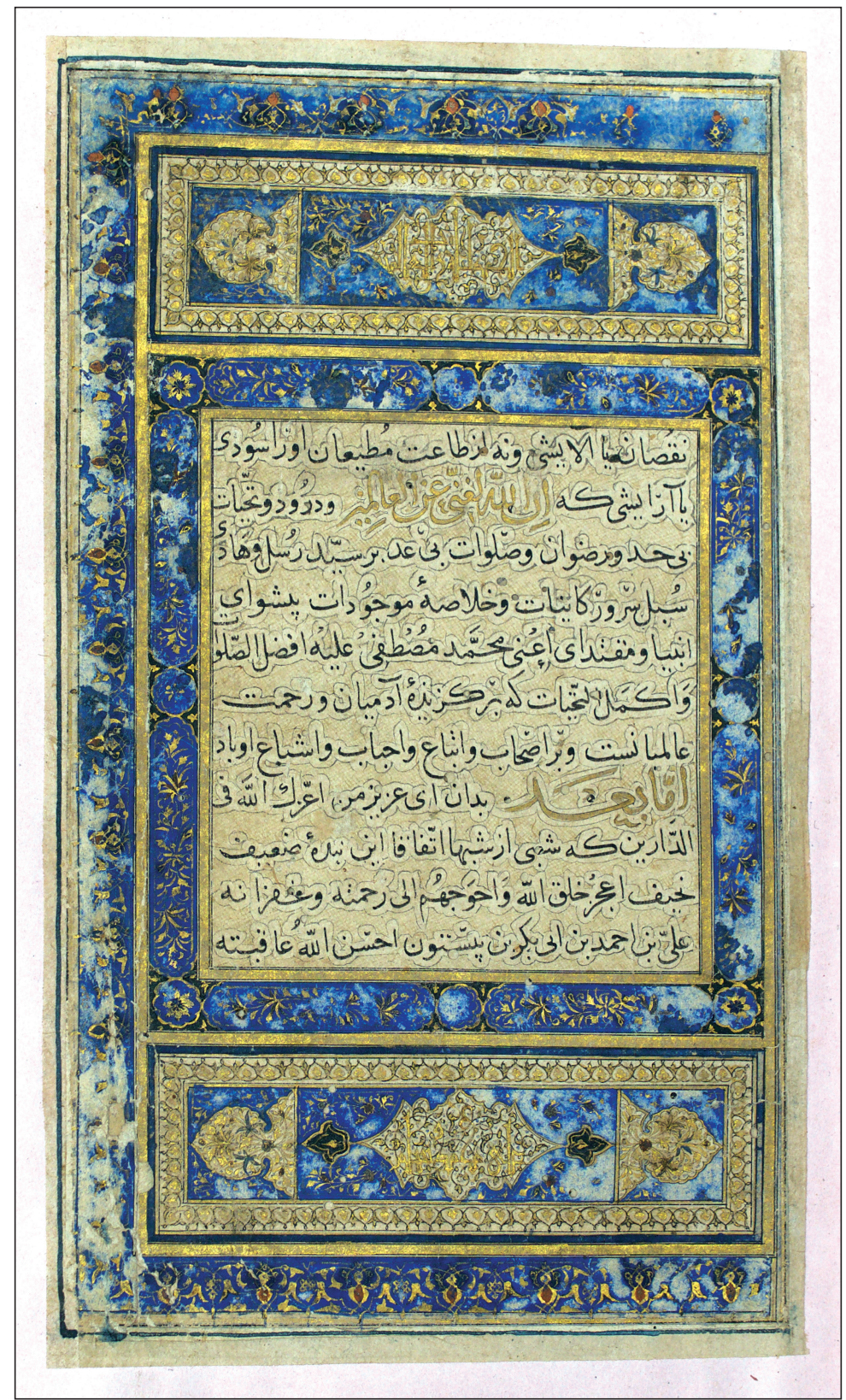

FIGURE 7. Illuminated text page, Kulliyat, 1370s-90s, Shiraz (probably). Oxford, Bodleian Library, MS Elliott 220, fol. 3a. (c) The Bodleian Library, University of Oxford. 
the larger areas of illumination discussed above. The other (later) headpieces are all in very good condition, which suggests that the manuscript may have suffered some damage at an early stage. ${ }^{33}$ Aside from the double frontispiece, double illuminated text pages, and headpieces, there are also two instances of decorated, upturned triangular-shaped inscriptions, although one of these has been partially lost (fol. 4a). Where visible (on fol. 8a), these inscriptions are flanked by right-angled trapezoid shapes on either side that are filled with delicate gold florals on solid blue ground (fig. 9). The first risala (treatise) ends on folio $8 \mathrm{a}$, so the inscription present is a colophon of sorts, though it does not contain any information about production or patronage. This way of decorating colophons is seen from at least the 1330s and was popular through to the fifteenth century. ${ }^{34}$ However, in the fifteenth century, it is more common to see the gold floral sprays or scrollwork appear on the bare ground of the paper, often accompanied by small orange blossoms. ${ }^{35}$ The 1365 copy of Tarjuma-i Mawlud-i Mustafa mentioned previously also features blue trapezoidal shapes with gold floral decoration that are very similar to those seen in the Bodleian Kulliyat (fig. 10).

The similarities in script colors and decorated inscriptions between the Bodleian Kulliyat and the 1365 Tarjuma-i Mawlud-i Mustafa might initially suggest that the former may have been produced in the 1360s. However, a closer look at the Kulliyat's illumination indicates that the date of production is likely somewhat later, probably between the 1370s and 1390s. The presence of thin gold bands in the frontispiece and illuminated text pages suggests that the manuscript dates to the 1370s or later. From around 1370, frame dividers in Muzaffarid manuscripts moved from thin, gold strapwork to the plain gold bands that are visible in the Bodleian Kulliyat. ${ }^{36}$ Strapwork is not present anywhere in the manuscript. The frontispiece and illuminated text pages also feature "palmette-arabesque" outer borders that are somewhat damaged but appear to resemble similar types of border decoration

33 Genuine lapis lazuli pigment is highly soluble and therefore washes away with relative ease which could explain the damage (many thanks to Karin Scheper for this information).

34 See Wright, The Look of the Book, 12, fig. 7.

35 See Wright, The Look of the Book, 81, fig. 50.

36 Wright, The Look of the Book, 58. 


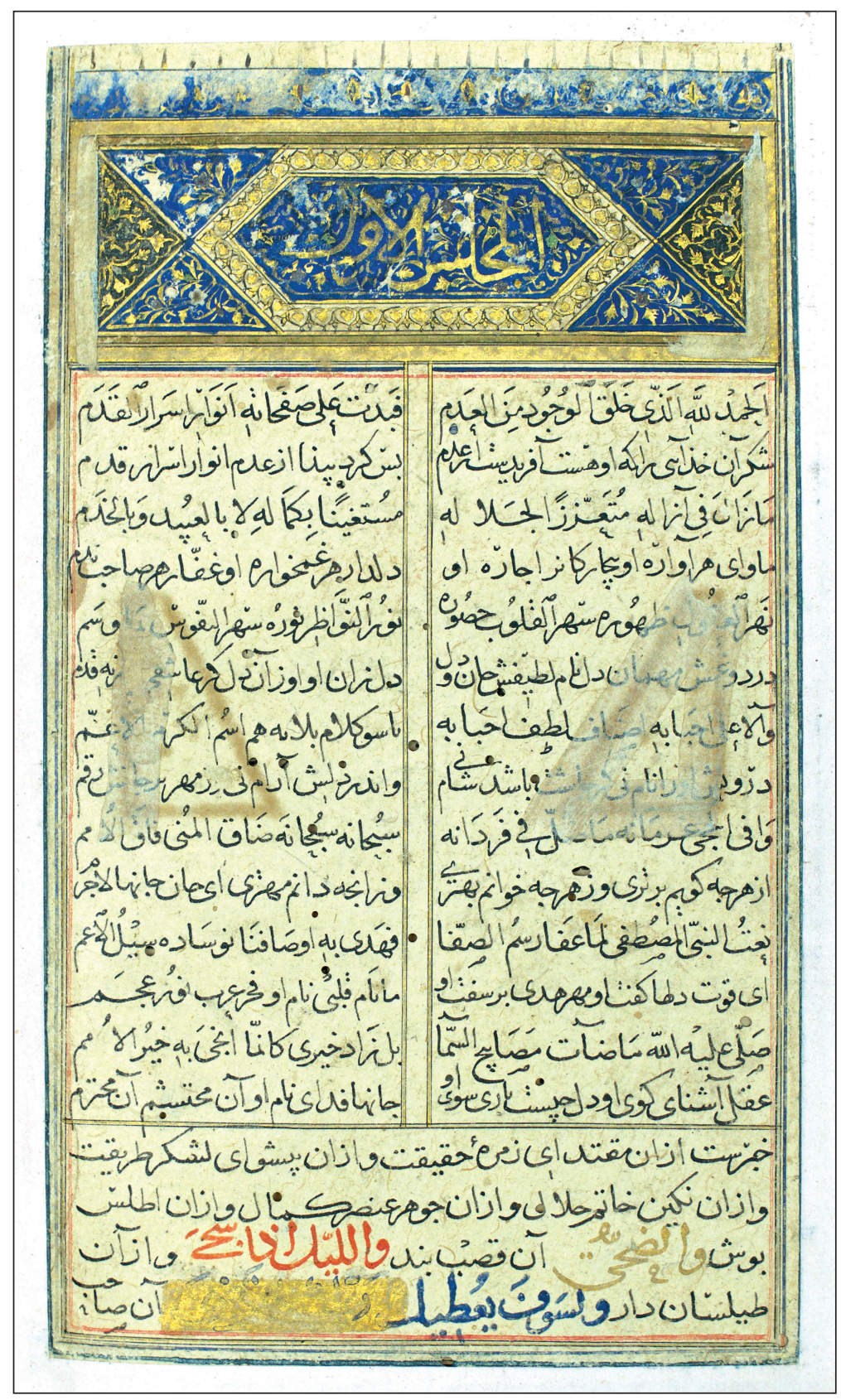

FIGURE 8. Headpiece for al-Majlis al-Awwal (part one of the Second Risala), Kulliyat, 1370s-90s, Shiraz (probably). Oxford, Bodleian Library, MS Elliott 220, fol. 8b. (C) The Bodleian Library, University of Oxford. 


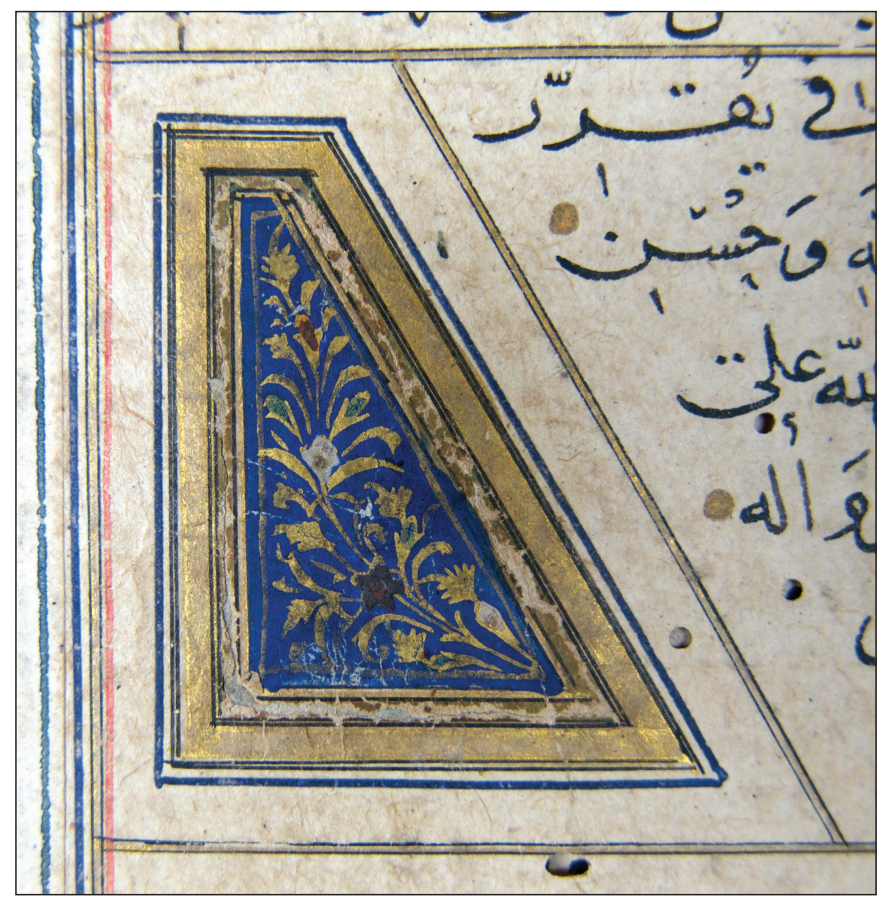

FIGURE 9. Decorated colophon (detail), Kulliyat, 1370s-90s, Shiraz (probably). Oxford, Bodleian Library, MS Elliott 220, fol. 8a. (c) The Bodleian Library, University of Oxford.

seen in Muzaffarid manuscripts from the 1360 s onwards. ${ }^{37}$ In terms of its specific design, it is particularly similar to a border in a copy of Jalal al-Din Rumi's Divan-i Kabir from 774/1372 that was almost certainly produced in Shiraz (Appendix, no. 6) (see fig. 1). ${ }^{38}$ There is also a "lotus-and-bud"-style border present in the frontispiece framing the central circle and square and in the illuminated text pages framing the upper and lower panels (see figs. 6-7). Once again, the "lotus-and-bud"-style border appears in Muzaffarid

37 Wright, The Look of the Book, 57 (fig. 35), 58.

38 Khamsa: Oxford, Bodleian Library, MS Ouseley 274-75, 2: fol. 1b (for other pages of this manuscript, see Wright, The Look of the Book, 56-57, figs. 33 and 35); Divan-i Kabir: London, British Library, Or. 2866, fol. 2b. On this manuscript, see Charles Rieu, Supplement to the Catalogue of the Persian Manuscripts in the British Museum (London: British Museum, 1895), no. 243. 


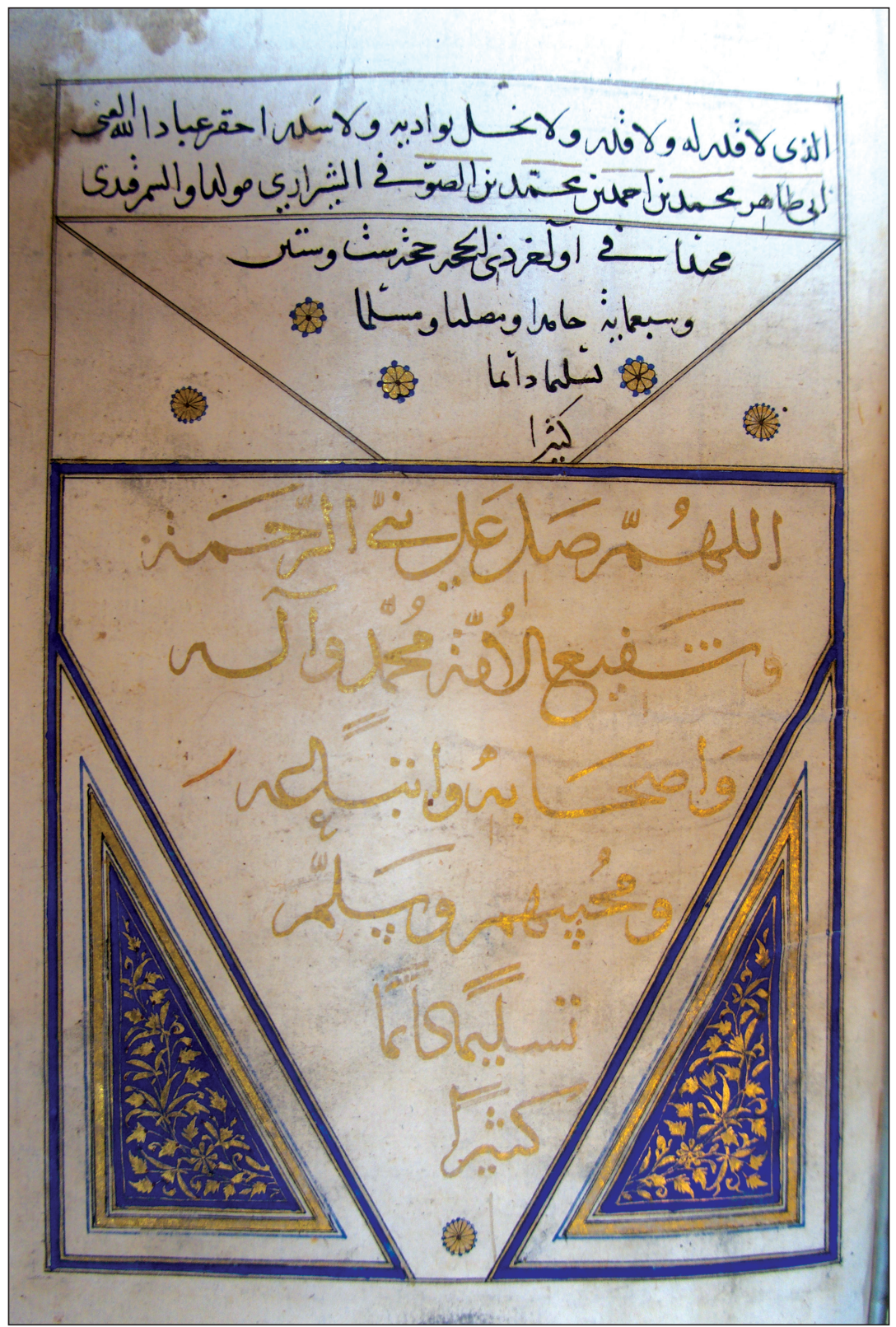

FIGURE 10. Decorated colophon, Tarjuma-i Mawlud-i Mustafa, 1365, Shiraz (probably). Oxford, Bodleian Library, MS Pers. d. 31, fol. 327a. (C) The Bodleian Library, University of Oxford. 
manuscripts from the 1360s onwards, often executed in gold and white. However, it is worth noting that, in the Bodleian manuscript, the border is executed fully in gold. The earliest instance thus far of a similarly miniaturized, fully gold "lotus-and-bud"-style border appears in a copy of the Divan of 'Imad al-Din 'Ali Faqih produced in 786/1384 in Shiraz (Appendix, no. 12). ${ }^{39}$

A distinctive feature of the borders of the Bodleian Kulliyat is the increasingly complex division of the decorated frames. This style would become very common in Timurid illumination. The frontispiece and the illuminated text pages feature not only the aforementioned thin gold bands, "palmette-arabesque" borders and "lotus-and-bud" borders, but also thicker borders around the central panel (and, in the case of the frontispiece, the upper and lower panels) that are divided into smaller cartouche-like shapes and roundels and decorated with delicate gold floral sprays. In full-page illuminations from the Muzaffarid period, this highly divided style of framing is not common, generally speaking. At most, one usually sees thin gold and green bands paired with either "palmette-arabesque" or "lotus-andbud" borders. However, there are a couple of examples of more complex border styles appearing from the 1370s. For instance, the colophon of a copy of the Shabnama produced in 772/1371 in Shiraz is decorated with yellow right-angled trapezoids and bordered on the left and right sides with frames containing circles and ovals (Appendix, no. 9) (see fig. 3). ${ }^{40}$ A Shirazi copy of Nizami's Khamsa from 776/1374-75 also features rather elaborately divided and colorful frames (Appendix, no. 8) (see fig. 2). ${ }^{41}$

39 Paris, Bibliothèque nationale de France, Supplément persan 745, fol. 1b. For an image of this folio, see Richard, Splendeurs Persanes, no. 27.

40 Istanbul, Topkap1 Palace Museum, H. 1511, fol. 288a. On this manuscript, see J. M. Rogers, ed., The Topkapi Saray Museum: The Albums and Illustrated Manuscripts (London: Thames and Hudson, 1986), 89, no. 54; Bernard O'Kane, "The Iconography of the Shabnama, MS Ta'rikh Farisi 73, Dar al-Kutub, Cairo (796/1393-4)," in Shabnama Studies, ed. Charles Melville and Gabrielle Van den Berg (Cambridge: Centre of Middle Eastern and Islamic Studies; Leiden: Brill, 2006), 171-88, 175-76; and Wright, The Look of the Book, 159, fig. 82, 161, fig. 86.

41 Istanbul, Topkap1 Palace Museum, H. 1510, fols. 499b-500a. On this manuscript, see Priscilla P. Soucek and Filiz Çağman, "A Royal Manuscript and Its Transformation: The Life 
In the center of the Kulliyat's frontispiece is a small polylobed medallion (perhaps intended for an inscription since it is filled with plain gold only) surrounded by twelve small inscribed circles specifying the manuscript's contents. Polylobed medallions were very common from the early fourteenth century in Persian illumination (and, indeed, well into the fifteenth century), as were small inscribed circles. The combination of the two motifs together is more unusual. ${ }^{42}$ In the context of Muzaffarid or early Timurid Shiraz, I have not been able to find an exact parallel for the frontispiece design in manuscript illumination. However, a copy of the Kulliyat of Sa di from the mid-fourteenth century, perhaps produced in Shiraz, ${ }^{43}$ and a copy of the Kulliyat of 'Imad al-Din 'Ali Faqih from 772/1370 (Appendix, no. 5), most likely from Shiraz, both feature eight small inscribed circles surrounding a small circle medallion. ${ }^{44}$ Additionally, an extensively illuminated and illustrated poetry anthology from the very early years of Timurid rule produced in 801/1398 features two small medallions-one pointed ovalshaped and one polylobed-that contain several small inscribed circles arranged in a circle shape (Appendix, no. 13) (fig. 11)..$^{45}$ The design of small inscribed circles arranged into a larger circle also appears in later Timurid illumination from the mid-fifteenth century. ${ }^{46}$

History of a Book," in The Book in the Islamic World: The Written Word and Communication in the Middle East, ed. George N. Atiyeh (Albany: State University of New York Press, 1995), 179-208.

42 For mid-fourteenth-century examples of both motifs, see Wright, The Look of the Book, 22-26, figs. 16-18; 55, fig. 32.

43 Wright, The Look of the Book, 17, fig. 17.

44 Saint Petersburg, National Library of Russia, MS Dorn 406, fol. 2a. This folio is illustrated in Akimushkin and Gray, The Arts of the Book in Central Asia, 43, fig. 20. There is also a small bronze casket that features polylobed medallions surrounded by small circles. A. S. Melikian-Chirvani ascribed this object to thirteenth-century Iran, but the Victoria and Albert Museum website lists it as originating in the fifteenth or sixteenth century: "Casket," Victoria and Albert Museum, accessed 20 June 2019, http://collections.vam.ac.uk/item/O114703/ casket/; and A. S. Melikian-Chirvani, Islamic Metalwork from the Iranian World: 8th-18th Centuries (London: Her Majesty's Stationery Office, 1982), cat. no. 82.

45 Istanbul, Museum of Turkish and Islamic Arts, 1950, fols. 288a, 542a. The frontispiece of this manuscript also features four small inscribed circles at the center of the illuminated double frontispiece. See O'Kane, “The Bihbihani Anthology," 14, fig. 13.

46 Wright, The Look of the Book, 60, fig. 37. 
Manuscript Studies, Vol. 5 [2021], Iss. 2, Art. 2

Jackson, Fourteenth-Century Shiraz

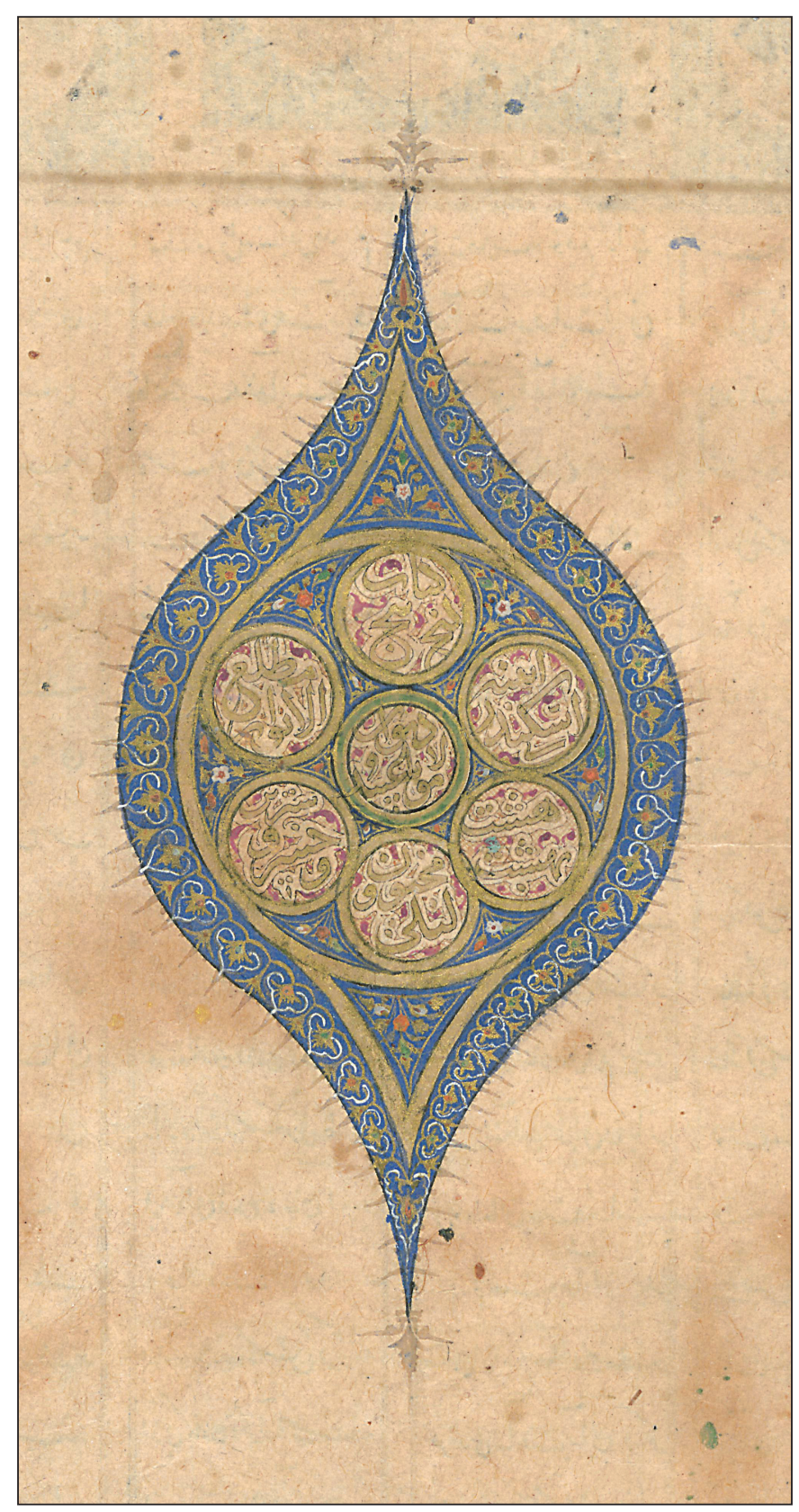

FIGURE 11. Pointed oval frontispiece, Anthology, 1398, Shiraz (probably). Istanbul, Museum of Turkish and Islamic Arts, 1950, fol. 288a. (C) Türk ve İslam Eserleri Müze Müdürlüğü. 
The cartouche that appears in the center of the frontispiece's upper and lower panels (fols. 1b-2a; see fig. 6) is of a shape seen in many illuminations from the 1360s through to the early fifteenth century. For example, it appears in the headpiece of a 763/1362 copy of Nizami's Khamsa (Appendix, no. 7) as well as in an 815-16/1412-13 copy of Matla al-Anwar by Amir Khusraw Dihlavi dedicated to the Timurid prince Iskandar Sultan (d. 1415), both from Shiraz (Appendix, no. 14). ${ }^{47}$ The cartouche design that appears on the illuminated text pages of the Kulliyat (fols. 2b-3a; see fig. 7) is of the "baroque-edged" or "irregular" variety that was common in the Muzaffarid and Timurid manuscript decoration. ${ }^{48}$ The specific form of the cartouche finds a near-identical parallel in a copy of Abu-1-Ma'cali Nasrallah Munshi's Kalila wa Dimna, which Elaine Wright has dated to around 1380-90 (Appendix, no. 15). ${ }^{49}$ This is the only close visual similarity found among the many "baroque-edged" cartouches from this period. The two cartouches follow exactly the same contours, although the example from the Kulliyat is more stretched along the horizontal axis.

As mentioned above, there is only one headpiece from the Kulliyat's original program of illumination (fol 8b; see fig. 8). Its cartouche is inscribed with the title al-Majlis al-Awwal (part one of the Second Risala). It consists of bands that cross to form a central flattened hexagon flanked by two triangles. Although a relatively simple design, a similar motif in a Persian manuscript dated earlier than 800/1398 (Appendix, no. 16) has not yet emerged. In this manuscript from $800 / 1398$, which is a collection of epic poems split between two libraries, the hexagonal motifs appear on several illuminated

47 Khamsa: Paris, Bibliothèque nationale de France, Supplément persan 1817, fol. 18b. For this folio, see "Nezāmi. Khamseh," Gallica, Bibliothèque nationale de France, published online on 27 February 2019, https://gallica.bnf.fr/ark:/12148/btv1b84272541/f40.item. Matlac alAnwar: Lisbon, Museu Calouste Gulbenkian, MS L.A. 158, fol. 2b. On this folio, see Yael Rice, “An Early Fifteenth-Century 'Khamsa' from Shiraz in the Bryn Mawr Library," Muqarnas 28 (2011): 265-81, 276, fig. 17.

48 See, for example, Wright, The Look of the Book, 56-57, figs. 33-35.

49 Paris, Bibliothèque nationale de France, Persan 377, fol. 2b. For this folio, see "Kalìla va Dimna," Gallica, Bibliothèque nationale de France, published online on 27 February 2019, https://gallica.bnf.fr/ark:/12148/btv1b8410889v/f14.item. See also Wright, The Look of the Book, 164 (Table 12d); and Richard, Splendeurs Persanes, no. 29. 
text pages, although their execution is markedly more complex and elaborate than what is present in the Bodleian Kulliyat manuscript. ${ }^{50}$ The flattened hexagon shape also appears on the leather binding of a Shabnama manuscript produced in Shiraz in 842/1439 and in the illumination of a copy of the Kulliyat of Sa di from around 1440, also produced in Shiraz. ${ }^{51}$

The final motif discussed in relation to the Bodleian Kulliyat is the "cutoff" cloud collar motif that appears on either side of the inscribed cartouches in the illuminated text pages' upper and lower panels. Both "cut-off" forms and cloud collar motifs were common in Muzaffarid illumination from the 1360s. ${ }^{52}$ Cloud collar motifs were employed by Muzaffarid and Timurid illuminators and manipulated to form a variety of complex illuminated designs, such as cruciform shapes. ${ }^{53}$ Many forms of illumination in these later periods, in fact, were derived from the cloud collar motif. ${ }^{54}$ In the Kulliyat, the cloud collar form appears on its side, sitting atop a wide, flat base. Although cloud collar motifs appear in manuscripts from throughout the Muzaffarid and early Timurid periods, there are only a few instances of the motif appearing in this specific way. The earliest example that I have come across is from the aforementioned poetry anthology from 801/1398 (Appendix, no. 13). In this manuscript, one headpiece consists of a central pointed oval cartouche that is flanked by two sideways cut-off cloud collar motifs (fig. 12). ${ }^{55}$ A sideways cloud collar-like motif also appears in the headpiece of a copy of Taj al-Ma'athir by Hasan Nizami (fl. 12th-13th

50 London, British Library, Or. 2780, fols. 41b-42a, 134b-135a; Dublin, Chester Beatty Library, Per 114. On the illumination of the British Library portion, see "Or 2780," British Library, Digitised Manuscripts, accessed 13 June 2019, http://www.bl.uk/manuscripts/Full Display.aspx?ref=Or_2780. For illustrations from the Chester Beatty portion, see Wright, The Look of the Book, 168, fig. 89; and "Shabnama," Explore Islamic Art Collections, Museum With No Frontiers, accessed 17 June 2019, http://islamicart.museumwnf.org/database_item. php?id=object;EPM;ir;Mus21;20;en.

51 On both, see Wright, The Look of the Book, 73, fig. 44; 277, fig. 135.

52 For an example of both motifs, see Wright, The Look of the Book, 56, fig. 33, where the "cut-off" form is adjacent to the circular medallions and the cloud collar shape forms the sides of the "baroque-edged" cartouche.

53 See, for example, Wright, The Look of the Book, 75, fig. 45.

54 Wright, The Look of the Book, 69.

55 Istanbul, Museum of Turkish and Islamic Arts, 1950, fol. 86b. 


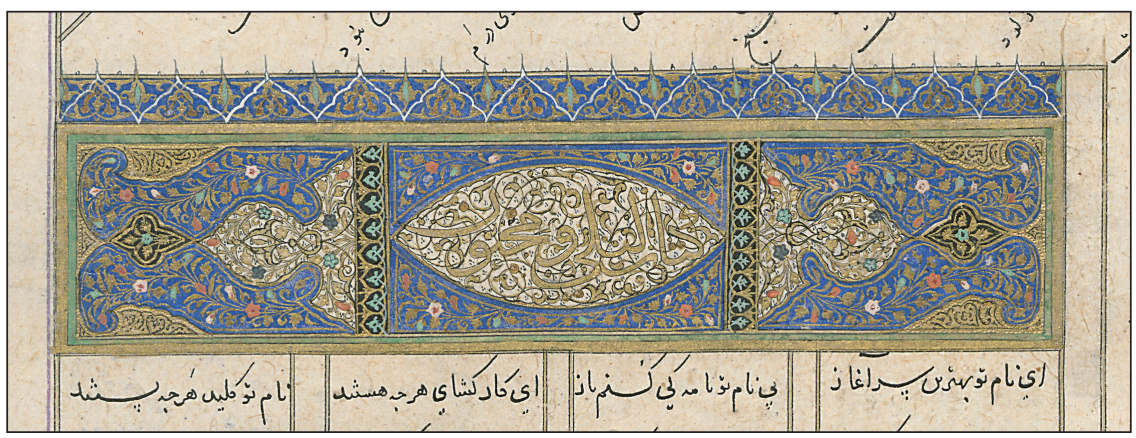

FIGURE 12. Headpiece for Kitab-i Layla u Majnun, Anthology, 1398, Shiraz (probably). Istanbul, Museum of Turkish and Islamic Arts, 1950, fol. 86b. (C) Türk ve İslam Eserleri Müze Müdürlüğü.

centuries) that was produced in Kerman in 781/1380 (Appendix, no. 10) ${ }^{56}$ and makes further appearances in Timurid manuscripts from the early to mid-fifteenth century. ${ }^{57}$

\section{Conclusions}

Given the numerous similarities between the illumination of the Bodleian Kulliyat and contemporary illumination from Shiraz, we can say with confidence that the manuscript was produced there. However, due to the continued use of many aspects of illumination throughout the late fourteenth and early fifteenth centuries in Shiraz, it is difficult to be precise about when the Bodleian Kulliyat may have been produced, especially given that no information about its artists or possible patrons has survived. Furthermore, this lack of information about patronage and dating makes it challenging to know precisely how this manuscript fits into the broader developmental narrative of fourteenth- and fifteenth-century Persian illumination and manuscript production.

56 Richard, Splendeurs Persanes, no. 26.

57 Wright, The Look of the Book, 72-73, figs. 43-44; Rice, "An Early Fifteenth-Century 'Khamsa',' 276, figs. 16-17. 
There are several elements of the illumination that could link the manuscript to the 1370s-90s. The presence of thin, gold bands suggests a date after 1370. Both the fully gold "lotus-and-bud" borders and the complex division of frames are not seen in Muzaffarid illumination until the 1370s and 1380 s but seem to be increasingly common from the 1390s. The design of inscribed circles surrounding a polylobed medallion does not reveal much in the way of dating, since both motifs were common in Shirazi illumination from at least the mid-fourteenth century. Similarly, the scallop-edged cartouche featured in the frontispiece is another motif that appears in several late fourteenth- and early fifteenth-century manuscript illuminations.

However, the cartouches that appear in the illuminated text pages and in the headpiece on folio $8 \mathrm{~b}$ seem to relate to manuscript illumination dating from the 1380s and 1390s. The "baroque-edged" cartouches that appear on the illuminated text pages are of a general form that is commonplace in Muzaffarid illumination, but only one near-exact parallel has been found, in a manuscript produced around 1380-90. The flattened hexagon motif in the headpiece panel has, so far, only been located in manuscript illumination from 800/1398. Finally, the sideways, "cut-off" cloud collar also seemingly makes a relatively late appearance in the context of Muzaffarid illumination, only featuring in a very early Timurid manuscript dating from $801 / 1398$.

One element of illumination could potentially shift the possible date of the manuscript toward the earlier part of the suggested window of the 1370s-90s: the blue right-angled trapezoids decorated with gold floral sprays that appear on either side of the short inscription (see fig. 9). The only close visual comparison to this appears in a manuscript dating from 766/1365 (see fig. 10). This same manuscript also contains words and phrases written in black, bright blue, bright red, and dark red, which is otherwise unusual for text blocks of this period. These notable similarities to a manuscript from 1365 could suggest that a production date of the 1370s is more likely than that of the 1390s. The Kulliyat is also written in naskb, which, for a text containing many works of poetry, is surprising - but not unheard of - for the later fourteenth century. This again could support the hypothesis of a 1370 s dating. If new evidence is discovered in future research, it may be possible to narrow down the proposed 1370s-90s date range. 


\section{Appendix}

Muzaffarid and early Timurid manuscripts discussed in this article (in order of citation)

1. Kulliyat (Collection), Sacdi (d. 1292), 1370s-90s, Shiraz (probably). Oxford, Bodleian Library, MS Elliott 220

2. Hada'iq al-Anwar wa-Bada'i' al-Asb'ar (Gardens of Flowers and Wonders of Verse), Junayd ibn Mahmud ibn Muhammad (fl. late 14th c.), Rabi' I 790/ March-April 1388, Shiraz or Yazd (probably), Junayd ibn Mahmud ibn Muhammad (scribe, possibly), Shah Yahya (d. 1390s, patron). Paris, Bibliothèque nationale de France, Arabe 3368

3. Miftah al-Khaza'in (Key of the Treasuries), Zayn al-'Attar (d. 1403-4), 14 Dhu-1-Qa'da 767/23 July 1366, Shiraz (probably), Zayn al-'Attar (scribe). Oxford, Bodleian Library, MS Marsh 491

4. Qur'an, 1340s-50s (with additional illumination from the early 1370s), Shiraz, Fars Malik Khatun (original patron), Turanshah (later patron). London, Khalili Collection, QUR 181

5. Kulliyat (Collection), 'Imad al-Din 'Ali Faqih (d. ca. 1371), 772/1370 [precise dating currently unknown], Shiraz (probably), Amir Rukn al-Din Hasan al-Shirazi (patron). Saint Petersburg, National Library of Russia, MS Dorn 406

6. Divan-i Kabir (The Great Works), Jalal al-Din Rumi (d. 1273), 1 Jumada II 774/27 November 1372, Shiraz (probably), Ahmad ibn Vali al-Shirazi (scribe). London, British Library, Or. 2866

7. Khamsa (Quintet), Nizami Ganjavi (d. 1209), 1 Sha'ban 763/26 May 1362, Shiraz (probably), Ahmad ibn al-Husayn al-Sana (scribe). Paris, Bibliothèque nationale de France, Supplément persan 1817

8. Khamsa (Quintet), Nizami Ganjavi (d. 1209), Rajab 776/December 1374-January 1375, Shiraz, Lutfallah ibn Yahya ibn Muhammad al-Tabrizi known as Kamal al-Jalali (scribe and illuminator). Istanbul, Topkapı Palace Museum, H. 1510 (fols. $499 a-775 b)$

9. Shabnama (Book of Kings), Abu-1-Qasim Firdawsi (d. 1020), Shawwal 772/ April-May 1371, Shiraz, Mas'ud ibn Mansur ibn Ahmad al-Mutatabbib (scribe). Istanbul, Topkapı Palace Museum, H. 1511

10. Taj al-Ma'athir (The Crown of Memorable Deeds), Hasan Nizami (fl. 12th-13th centuries), Shawwal 781/January-February 1380, Kerman, Faraj ibn Karim al-Mutatibb (scribe). Paris, Bibliothèque nationale de France, Persan 276

11. Tarjuma-i Mawlud-i Mustafa (Translation of the Birth of the Prophet Muhammad), Sa id al-Din al-Kazaruni (d. 1357, author), 'Afif al-Din (translator), end of Dhu-1-Hijja 766/September 1365, Shiraz (probably), Abu Tahir Muhammad ibn Ahmad ibn al-Sufi al-Shirazi mawlidan wa-1-Samarqandi mabtidan (scribe).

Oxford, Bodleian Library, MS Pers. d. 31

12. Divan, 'Imad al-Din 'Ali Faqih (d. ca. 1371), 30 Muharram 786/24 March 1384, Shiraz, Mansur ibn 'Ali ibn Muhammad ibn al-Husayn al-Tusi Muhammad 
al-Kashi (scribe), Rukn al-Din Abu Sacid (patron). Paris, Bibliothèque nationale de France, Supplément persan 745

13. Anthology, Muharram 801/September-October 1398, Shiraz (probably), Mansur ibn Muhammad ibn Varqa ibn 'Umar ibn Bakhtiyar Bihbihani (scribe). Istanbul, Museum of Turkish and Islamic Arts, 1950

14. Matla' al-Anwar (The Lights' Dawn), Amir Khusraw Dihlavi (d. 1325), 815-16/ 1412-13, Shiraz (probably), Hasan al-Hafiz (scribe), Iskandar Sultan (d. 1415, patron). Lisbon, Museu Calouste Gulbenkian, MS L.A. 158

15. Kalila wa Dimna (Kalila and Dimna), Abu-1-Máali Nasrallah Munshi (fl. late 12th century), ca. 1380-90, Shiraz (probably). Paris, Bibliothèque nationale de France, Persan 377

16. Anthology, 14 Rajab 800/2 April 1398, Shiraz (probably), Muhammad ibn Sa id ibn Sa'd ibn 'Abdallah ibn al-Hafiz al-Qari (scribe). London, British Library, Or. 2780; Dublin, Chester Beatty Library, Per 114 